\title{
COMPARATIVE WATER RELATIONS OF SOME TROPICAL MILLIPEDES
}

\author{
Somnath Bhakat \\ Department of Zoology, Rampurhat College, \\ Rampurhat731224, West Bengal, India. \\ E-mail: bhakatsomnath084@gmail.com
}

(Received August 8, 2013)

\begin{abstract}
Water content, percentage of total body water lost as a function of time, and cuticular permeability are determined for 10 species of millipedes representing three orders (Polydesmida, Spirobolida and Spirostreptida). Mean water content per cubic centimeter of body mass ranges from $422 \mathrm{mg}$ for Polydesmopeltis kelaarti to $886 \mathrm{mg}$ for yet undetermined Species B (Spirostreptida: Harpagophoridae). Mean percentage of total body water ranged from 57.46 for Orthomorpha coarctata to 70.21 for P. kelaarti. Mean cuticular permeability ranges from $20.28 \mu \mathrm{g} \mathrm{cm}^{-1} \mathrm{~h}^{-1} \mathrm{~mm} \mathrm{Hg}^{-1}$ for Gonoplectus malayusto $82.53 \mu \mathrm{g} \mathrm{cm}^{-1} \mathrm{~h}^{-1} \mathrm{~mm} \mathrm{Hg}^{-}$ ${ }^{1}$ for O.coarctata. Cumulative percentage of total body water lost at 20 hour varied widely ranging from $9.35 \%$ in G. malayus to $61.64 \%$ in $O$. coarctata.

Smaller millipedes (Polydesmida), having lower water reserve, higher CP values and higher rate of percent of TBW lost, are less tolerant to desiccation compared with larger species (Spirobolida and Spirostreptida). Analyzed polydesmids are restricted to hygric environments, whereas, spirobolids and spirostreptids can tolerate desiccation to a large extent and are confined to mesic or xeric habitats.
\end{abstract}

Key words: water content, total body water (TBW), cuticular permeability (CP), millipedes, habitat type.

\section{INTRODUCTION}

Water conservation is of major importance for terrestrial arthropods (CLOUDSLEYTHOMPSON, 1975). In order to prevent desiccation, most arthropods often possess a relatively impervious waxy integument (EDNEY, 1977). However, the frequent opening of respiratory spiracles associated with tracheal breathing leads to a net water loss during gas exchange. Moreover, terrestrial environments associated with soils and leaf litter, vary in moisture content and this may affect the degree to which arthropods experience desiccation stress. As such, soils, which can be classified as hygric (containing a high water content), mesic (containing a moderate amount of water), or xeric (containing a little water), may be associated with arthropods that differ in their water reserves, cuticular permeability and rates of water loss.

The cuticle of most species of millipedes is permeable to the water and this restricts their habitats to areas where the humidity is high (EDNEY, 1977). As such, in these groups water loss by transpiration tends to be proportional to the saturation deficiency of the atmosphere (Cloudsley-Thompson, 1960, 1961). Because these arthropods lose water rapidly in dry air at normal ambient temperatures, they tend to be restricted to moist cryptozoic micro habitats such 
as those found within soils, under stones, fallen leaves and within crevices (BLIGH et al., 1976). As millipedes vary greatly in size $(2 \mathrm{~mm}$ to $300 \mathrm{~mm})$, it is expected that water loss dynamics associated with body size will be evident.

Though water relations in different species of insects have been studied extensively (APPEL et al., 1983; MACK and APPEL, 1986; MACK et al., 1988; APPEL and SPONSLER, 1989; SPONSLER and APPEL, 1990; APPEL et al., 1991), studies on water relations in millipedes are scant (ClOUdSLEY-ThOMPSON, 1950; EdNEY, 1951; CrAWFORD, 1972; STEWART and WoODRING, 1973; APPEL, 1988) and there are no comparative studies on water relations in millipedes from different orders.

The objective of this study is to examine different aspects of water relations in 10 species of tropical millipedes including differences in their water content per unit volume, cuticular permeability (CP), total body water (TBW) loss and mortality, in the context of the types of environments they are found in and their overall sizes. In particular, in this study two hypotheses have been tested:

1) that a species' CP values will determine the types of environments they are associated with (hygric, mesic, or xeric); and

2) that differences in millipede body size will influence a millipede's ability to retain and conserve water. If water conservation is affected by water content in an environment, then it is expected that from hygric to xeric environment, $\mathrm{CP}$ values will be lowest for species inhabiting drier habitats and the rate of TBW lost also will be lowest for these species. If body size affects susceptibility to desiccation then it is predicted that small individuals will die earlier compared to larger ones.

\section{MATERIALS AND METHODS}

In this study, 12 millipede species found across different soil habitats (that varied in moisture content) and seasons were collected from several localities in the district Birbhum $\left(23^{0} 32^{\prime} 30^{\prime \prime} \mathrm{N}\right.$ to the $24^{0} 35^{\prime} \mathrm{N}$, and $87^{0} 5^{\prime} 25^{\prime \prime} \mathrm{E}$ to the $88^{0} 1^{\prime} 40^{\prime \prime} \mathrm{E}$ ) (West Bengal, India). Among them, 10 species were selected for experimentation as two species are minute $(<6 \mathrm{~mm})$ and difficult to handle.

Adult millipedes were collected by hand, randomly from their natural habitats, from June to September. Species A and Orthomorpha coarctata (Saussure, 1860) were strictly restricted to the moist decomposed leaf litter in shady areas. Species B was often found in grass fields with decomposed leaf litter or organic matter and within dry soils associated with animal litter, rotten vegetables, etc. Xenobolus carnifex (Fabricius, 1775), Trigoniulus lumbricinus (Gerstaecker,1873), Streptogonopus phipsoni (Pocock, 1892) and Anoplodesmus saussurii (Humbert, 1865 ) were found within grassy fields and open soils rich in organic matter as well as on wall surfaces covered with bryophytes and fungi. These later species were also mostly prevalent at the onset of rainy season. Polydesmopeltis kelaarti (Humbert,1865) and Chondromorpha severini (Silevestri,1897) were often found in the grass fields rich in organic matter and damp brick as well as in the wall surface rich in bryophytes. For these species, their habitats were strictly in shady areas, such as under the shadow of large trees. Gonoplectus malayus (Carl, 1909) was found along the banks of rivers, canals, or high ridge of soil covered with grasses. These species lives within holes and crevices as were strictly nocturnal, active during most months and occurred along a pronounced climatic moisture gradient (high and low moisture gradient in fall and winter respectively).

After collection, millipedes were held within large plastic pots (diameter $30 \mathrm{~cm}$ ) and maintained in the laboratory on moist soil (30-40\% water), decomposed leaves of jack fruit, mango and guava. Each species was placed within a separate pot. The millipedes were also provided daily with fresh water, pieces of cut potato, papaya, or cucumber. The cultures were maintained at about $75-80 \% \mathrm{Rh}$ and $26-29{ }^{\circ} \mathrm{C}$. Specimens were used in the experiments within a 
week of collection. For each experiment, ten species of millipedes (20 individuals per species) were used (Table 1).

The length and width of live adult millipedes were determined as described by BLOWER and GABBUT (1964), BLOWER and MiLLER (1977) and BHAKAT (1987). Surface area and volume of each specimen was estimated by considering the millipede as a cylinder and by using the following formulas: $\mathrm{h}=$ length.

Surface area $=2 \pi \mathrm{rh}$ and volume $=\pi \mathrm{r}^{2} \mathrm{~h}$, where, $\mathrm{r}=$ radius i.e. half of the width and

Each specimen was weighed separately by an analytical balance with accuracy up to 0.01 $\mathrm{mg}$ for estimation of simultaneous weight loss (see below) and final dry weight.

The water content, cuticular permeability (CP), and percentage of total body water (TBW) lost over 24 hour time was determined gravimetrically (APPEL et al., 1983; MACK and APPEL, 1986). For estimation of CP and percentage of TBW lost over time, millipedes were starved for one day prior to the experiment to avoid the variability of gut contents and the dropping of the fecal matter. After starving, individual millipedes were placed in open glass vials having different diameters $(2-8 \mathrm{~cm})$ and height $(3-6 \mathrm{~cm})$, which were then put into a large desiccator maintained at $30 \pm 1{ }^{0} \mathrm{C}$ and $0-2 \% \mathrm{Rh}$. Anhydrous $\mathrm{CaSO}_{4}$ was used in the desiccator as moisture drier which maintained the air in the chamber $0-2 \% \mathrm{Rh}$. The desiccator was then placed in an incubator maintained at $30 \pm 1{ }^{0} \mathrm{C}$. Over the next 24 hours, at four hour intervals each specimen was taken out of its vial, weighed and then returned to the vial as quickly as possible. After 24 hours weight losses were measured till death for all the specimens. The loss of body mass measures conducted every four hours and percentage of TBW measures (defined as the proportional difference between the initial weight of the live specimen and its successive weights throughout the experiment) were used to calculate percentage of TBW lost over time. After completion of the experiment, dry weight was determined by weighing the oven dried $\left(\right.$ at $60{ }^{\circ} \mathrm{C}$ ) specimen until two successive weighing did not differ. CP was determined using data from the first 4 hours of the desiccation experiment because this period represented the maximum water differential between the millipede and the desiccation chamber and thus the maximum rate of water loss for a given millipede. CP was calculated as the $\mu \mathrm{g}$ of water lost per unit surface area $\left(\mathrm{cm}^{2}\right)$ per unit time $(\mathrm{h})$ per unit saturation deficit $(\mathrm{mm} \mathrm{Hg})$ in a desiccation chamber.

The data were expressed as means \pm S.E. Linear regression analyses were employed to determine percentage of TBW lost over time and these rates were also correlated with millipede size. Q value (body volume to surface area) was calculated for each species and used to quantify the relationship between $\mathrm{CP}$ and mortality. t-tests were performed to determine the differences between water content and rates of percent of TBW lost in three millipede orders (polydesmida, spirostreptida and spirobolida).

\section{RESULT AND DISCUSSION}

\section{Water content}

Length, width and percentage of TBW are listed in Table 1. Initial body water content of the millipedes examined ranged from $57.46 \pm 2.04 \%$ for Orthomorpha coarctata to $70.21 \pm 0.89 \%$ for Polydesmopeltis kelaarti. These were within the range of non-insect arthropods (54-85\% TBW) summarized by EDNEY (1977) and in accordance with other millipedes. Among millipedes, for example other studies have shown that Oxidus gracilis (C. L. Koch, 1847) (Polydesmida) contained 60\% TBW (APPEL, 1988), while Spirostreptus syriacus (Spirostreptida) contained $44.5 \pm 1.4$ to $74.0 \pm 1.9 \%$ TBW in different geographic locations and seasons (CRAWFORD et al., 1986). DANGERFIELD and MILNER (1993) also reported that water content for Alloporus uncinatus (Attems, 1914) (Spirostreptida) was $66.04 \pm 0.64 \%$, while for Odontopyge sp. (Odontophygidae) was $60.35 \pm 0.02 \%$ and $59.34 \pm 3.57$ for Poratophilus sp. (Harpagophoridae). 

Table 1. Systematic position, measurements, water content, and percent of total body water of ten species of adult millipedes ( $\mathrm{n}=20$ ).

\begin{tabular}{|c|c|c|c|c|c|c|}
\hline \multirow{2}{*}{ Species } & \multicolumn{2}{|c|}{ Systematic position } & \multirow{2}{*}{$\begin{array}{c}\text { Length } \\
(\mathrm{mm})\end{array}$} & \multirow{2}{*}{$\begin{array}{l}\text { Width } \\
\text { (mm) }\end{array}$} & \multirow{2}{*}{$\begin{array}{c}\text { Water content } \\
\left(\mathbf{m g} / \mathrm{cm}^{3}\right)\end{array}$} & \multirow{2}{*}{$\begin{array}{c}\text { Percentage of } \\
\text { water }\end{array}$} \\
\hline & Order & Family & & & & \\
\hline Polydesmopeltis kelaarti & Polydesmida & Paradoxosomatidae & $27.09 \pm 0.51$ & $3.56 \pm 0.09$ & $422.08 \pm 2.45$ & $70.21 \pm 0.89$ \\
\hline Orthomorpha coarctata & Polydesmida & Paradoxosomatidae & $17.39 \pm 0.20$ & $1.85 \pm 0.05$ & $607.28 \pm 2.19$ & $57.46 \pm 2.04$ \\
\hline Anoplodesmus saussurii & Polydesmida & Paradoxosomatidae & $35.55 \pm 0.40$ & $4.22 \pm 0.07$ & $442.49 \pm 5.49$ & $66.20 \pm 1.41$ \\
\hline Streptogonopus phipsoni & Polydesmida & Paradoxosomatidae & $24.09 \pm 0.27$ & $2.81 \pm 0.07$ & $512.09 \pm 1.85$ & $62.46 \pm 1.23$ \\
\hline Species B & Spirostreptida & Harpagophoridae & $54.50 \pm 0.66$ & $3.09 \pm 0.06$ & $886.56 \pm 5.49$ & $59.42 \pm 3.08$ \\
\hline Genoplectus malayus & Spirostreptida & Harpagophoridae & $109.24 \pm 1.68$ & $8.00 \pm 0.11$ & $832.21 \pm 21.54$ & $63.20 \pm 4.23$ \\
\hline
\end{tabular}

Table 3. Cumulative percent of TBW lost as a function of time in ten species of millipedes ( $n=20)$.

\begin{tabular}{|c|c|c|c|c|c|c|c|}
\hline \multirow{2}{*}{ Species } & \multicolumn{6}{|c|}{ Cumulative percent of TBW lost at hour \pm SE } & \multirow{2}{*}{$\begin{array}{l}\% \text { of water } \\
\text { lost at death }\end{array}$} \\
\hline & 4 & 8 & 12 & 16 & 20 & $\underline{24}$ & \\
\hline Species A & $22.67 \pm 1.14$ & $36.03 \pm 2.25$ & $45.23 \pm 2.30$ & $47.58 \pm 1.56$ & $58.49 \pm 1.27$ & & $58.52 \pm 0.92$ \\
\hline P. kelaarti & $15.11 \pm 1.11$ & $24.87 \pm 1.95$ & $35.22 \pm 2.54$ & $44.16 \pm 3.50$ & $47.11 \pm 3.26$ & $56.45 \pm 3.27$ & $69.14 \pm 1.24$ \\
\hline C. severini & $12.56 \pm 0.56$ & $21.50 \pm 1.01$ & $29.05 \pm 1.32$ & $36.01 \pm 1.61$ & $43.91 \pm 1.62$ & $51.26 \pm 2.10$ & $61.72 \pm 0.85$ \\
\hline O. coarctata & $26.41 \pm 1.29$ & $38.66 \pm 1.93$ & $48.00 \pm 2.17$ & $53.52 \pm 1.79$ & $61.64 \pm 0.83$ & & $63.46 \pm 1.27$ \\
\hline A. saussurii & $10.32 \pm 0.33$ & $18.05 \pm 0.65$ & $24.68 \pm 0.90$ & $30.04 \pm 1.08$ & $34.68 \pm 1.15$ & $38.72 \pm 1.22$ & $79.66 \pm 2.14$ \\
\hline S. phipsoni & $10.78 \pm 0.32$ & $15.48 \pm 0.57$ & $20.64 \pm 1.10$ & $26.58 \pm 1.33$ & $31.79 \pm 1.66$ & $36.90 \pm 2.23$ & $71.67 \pm 1.25$ \\
\hline X. carnifex & $10.01 \pm 0.44$ & $17.16 \pm 0.51$ & $24.35 \pm 0.62$ & $31.79 \pm 0.79$ & $38.90 \pm 0.96$ & $49.22 \pm 1.14$ & $71.63 \pm 0.58$ \\
\hline T. lumbricinus & $5.60 \pm 0.39$ & $9.20 \pm 0.56$ & $13.45 \pm 0.83$ & $18.03 \pm 1.07$ & $22.89 \pm 1.15$ & $27.42 \pm 1.24$ & $73.29 \pm 0.89$ \\
\hline Species B & $4.82 \pm 0.33$ & $7.11 \pm 0.35$ & $9.49 \pm 0.41$ & $10.99 \pm 0.46$ & $13.32 \pm 0.64$ & $15.81 \pm 0.79$ & $68.35 \pm 1.27$ \\
\hline G. malayus & $2.79 \pm 0.11$ & $4.66 \pm 0.19$ & $6.41 \pm 0.24$ & $7.92 \pm 0.25$ & $9.35 \pm 0.27$ & $10.75 \pm 0.32$ & $77.01 \pm 1.25$ \\
\hline
\end{tabular}



As a general principle, BUXTON (1932) stated that the percentage of water content per mass decreases as an insect increases in size. This, he argued, was the result of a relative increase in the proportion of the total mass contributed by the cuticle in larger animals. BARLOW (1957), however, show no correlation between 'body weight' (presumably fresh weight) and the proportion of dry matter to the water for Ommatoiulus sabulosus (Linnaeus, 1758), Cylindroiulus punctatus (Leach, 1815), and Julus scadinavius Latzel, 1884. He concluded that these millipedes were not in keeping with Buxton's principle. In this study water content in proportion to dry matter were also not correlated (largest millipede G. malayus and smallest millipede species A contain $171 \mathrm{mg}$ and $177 \mathrm{mg}$ of water / $100 \mathrm{mg}$ of dry matter respectively). Water content per unit body volume depicts water reservoir of a species better than the total body water (TBW) (Table 1). This shows that $P$. kelaarti contains less water $\left(422 \mathrm{mg} / \mathrm{cm}^{3}\right)$, relative to Species B $\left(886 \mathrm{mg} / \mathrm{cm}^{3}\right)$. Moreover, in the polydesmidan (small in size in respect to other analyzed species belonging to other two orders) water content is low $\left(543.59 \mathrm{mg} / \mathrm{cm}^{3}\right)$ but other larger millipedes (belonging to spirostrepitdan and spirobolidan) contain greater amounts of water (mean value for four species was $\left.809.71 \mathrm{mg} / \mathrm{cm}^{3}\right)(\mathrm{t}=870.20, \mathrm{P}<0.01)$. Spirostreptida $(G$. malayus and Species B) contained more water than the two analyzed spirobolidans (X. carnifex and T. lumbricinus)suggesting that greater water reserves (per unit volume) may be an important adaptation for living in comparatively dry habitats (towards xeric habitat).

\section{Cuticular permeability}

For all species, the greatest rate of water loss occurred within the first $4 \mathrm{hr}$ then gradually decreased (Table 3). In insects, decelerating water loss at any given temperature may be due to the overlapping of sclerites or closer packing of cuticle elements as during dehydrates (BURSELL, 1955; LOVERIDGE, 1980).

Table 2 shows the $\mathrm{CP}$ of 10 species of millipedes. The greatest mean $\mathrm{CP}$ was $82.53 \pm 2.78 \mu \mathrm{g} \mathrm{cm}^{-2} \mathrm{~h}^{-1} \mathrm{~mm} \mathrm{Hg}^{-1}$ for $O$. coarctata and lowest mean CP was $20.28 \pm 1.23 \mu \mathrm{g} \mathrm{cm}^{-2} \mathrm{~h}^{-}$ ${ }^{1} \mathrm{~mm} \mathrm{Hg}^{-1}$ for $G$. malayus. When CP values were regressed with the ratio of body volume to area $(\mathrm{Q}$, Table 2) and length $(\mathrm{L})$ across species, $\mathrm{CP}$ values were found to decrease with increases in body size $(\mathrm{CP}=-38.4 \mathrm{Q}+88.7, \mathrm{r} 2=0.5592, \mathrm{P}<0.01$ and $\mathrm{CP}=0.63 \mathrm{~L}+76.16, \mathrm{r} 2=0.5401, \mathrm{P}<0.05$ respectively). These results would suggest that larger species, such as (G. malayus) are more desiccation resistant relative to smaller species $(O$. coarctata) and that increase in body size may be an adaptation for more mesic environments. In turn, the negative relationship between $\mathrm{CP}$ values and the timing of death when millipedes were placed within desiccation chambers (Mortality=197.17-2.36CP, $\mathrm{r} 2=0.4981, \mathrm{P}<0.05$ ) shows that lower CP values provide species with a greater ability to resist desiccation. Millipede having low CP value (20.28 in G. malayus) for example, survived for a longer period $(303.72 \mathrm{~h})$ compared to the millipede that have high $\mathrm{CP}$ values (O. coarctata, CP-82.53, died within 21.45 h). Edney (1977) classified the types of habitats that given arthropods may be adapted based on their $\mathrm{CP}$ values. Habitats were classified as xeric, mesic, and hygric if they correspond to $C P$ values of $<25,25-40$, and $>40$ respectively. Like other studies that have been found a relationship between $\mathrm{CP}$ values and the moisture content associated with their environments (EDNEY, 1951; MEAD-BRIGGS, 1956; CRAWFORD, 1972), this study found that Species A and $O$. coarctata are hygric (with CP values $\geq 40$ ) and $G$. malayus is truly xeric ( $\mathrm{CP}$ value $\leq 25$ ). However most species of millipedes inhabit, at least to some degree, mesic environments. So Edney's classification of habitat will be better fit if we consider CP along with the hour of death, and rate of \% of TBW lost. Thus a species may be transitional in between two habitats. On this principle, the habitats of 10 species of millipedes are listed in Table 2. The relationship between values of CP in consideration with long hours of death and minimum rate of \% of TBW lost may explain why Species B and G. malayus can survive hot and dry conditions with associated low soil moisture and high maximum daily temperatures, while other species of millipedes are restricted to habitats with high moisture content. 
Table 2. A species' surface to volume ratio $(\mathrm{Q})$, cuticular permeability $(\mathrm{CP})$, hour of death, and the type habitat it is associated with.

\begin{tabular}{lcccc}
\hline \multicolumn{1}{c}{ Species } & $\mathbf{Q}$ & CP $^{*}$ & Hour of death & Habitat \\
\hline Species A & 0.405 & $80.85 \pm 1.27$ & $20.35 \pm 0.82$ & Hygric \\
$P$. kelaarti & 0.89 & $75.76 \pm 2.14$ & $30.51 \pm 2.89$ & Hygric - Mesic \\
C. severini & 1.06 & $61.76 \pm 2.35$ & $40.51 \pm 5.11$ & Hygric - Mesic \\
O. coarctata & 0.463 & $82.53 \pm 2.78$ & $21.45 \pm 0.78$ & Hygric \\
A. saussurii & 1.055 & $45.21 \pm 3.15$ & $80.11 \pm 2.70$ & Mesic - Hygric \\
S. phipsoni & 1.423 & $30.58 \pm 0.83$ & $53.91 \pm 4.13$ & Mesic - Hygric \\
X. carnifex & 1.095 & $28.74 \pm 2.31$ & $40.81 \pm 2.22$ & Mesic - Hygric \\
T. lumbricinus & 0.955 & $43.80 \pm 0.49$ & $70.24 \pm 2.32$ & Mesic - Hygric \\
Species B & 0.773 & $28.83 \pm 0.89$ & $134.05 \pm 5.06$ & Mesic - Xeric \\
G. malayus & 2.0 & $20.28 \pm 1.23$ & $303.72 \pm 15.05$ & Xeric \\
\hline
\end{tabular}

${ }^{*} \mathrm{CP}$ in units of $\mu \mathrm{g} \mathrm{cm}^{-1} \mathrm{~h}^{-1} \mathrm{~mm} \mathrm{Hg}^{-1}$

Table 4. Regression equations for cumulative percentage of TBW lost over time (4 to $24 \mathrm{~h}$ ) for 10 species of millipedes $(\mathrm{P}<0.01)$.

\begin{tabular}{lcc}
\hline \multicolumn{1}{c}{ Species } & Regression equation & $\mathbf{r}^{\mathbf{2}}$ \\
\hline Species A & $\mathrm{Y}=2.08 \mathrm{x}+17.04$ & 0.957 \\
P. kelaarti & $\mathrm{Y}=2.02 \mathrm{x}+8.99$ & 0.988 \\
C. severini & $\mathrm{Y}=1.91 \mathrm{x}+5.64$ & 0.998 \\
O. coarctata & $\mathrm{Y}=2.13 \mathrm{x}+20.05$ & 0.980 \\
A. saussurii & $\mathrm{Y}=1.41 \mathrm{x}+6.37$ & 0.986 \\
S. phipsoni & $\mathrm{Y}=1.32 \mathrm{x}+5.15$ & 0.999 \\
$X$. carnifex & $\mathrm{Y}=1.92 \mathrm{x}+1.70$ & 0.996 \\
T. lumbricinus & $\mathrm{Y}=1.11 \mathrm{x}+0.63$ & 0.998 \\
Species B & $\mathrm{Y}=0.54 \mathrm{x}+2.50$ & 0.996 \\
G. malayus & $\mathrm{Y}=0.40 \mathrm{x}+1.45$ & 0.996 \\
\hline \multirow{2}{*}{$\mathrm{Y}=$ Cumulative percentage of TBW lost and $\mathrm{X}=$ Desiccation time in hours: } \\
\multicolumn{2}{c}{$\mathrm{n}=6$ for all species except Species A and O. coarctata $(\mathrm{n}=5)}$.
\end{tabular}

\section{Total Body Water loss and Mortality}

The mean percentage of TBW lost as a function of desiccation time is shown in Table 3. Rates of cumulative mass loss at $20 \mathrm{~h}$ ranged from $9.35 \pm 0.27 \%$ for G. malayus to $61.64 \pm 0.83 \%$ for $O$. coarctata. All species had a rapid initial rate of water loss within the initial four hours. This rapid loss of water is consistent with a multi-compartment water loss model which assumes that cuticular and extra cellular water is lost more rapidly than tissue or intracellular water (EDNEY, 1977; MACHIN, 1981).

An examination of the mean percentage of TBW lost over time across the species shows that an increase in body length led to a less rapid decline in the percentage of TBW lost over time (Table 5). Smaller species (Species A and O. coarctata) for example, rapidly lost their body water reserves and died within $20 \mathrm{~h}$, while larger species, such as G. malayus and Species B, lost body water reserves at a slower rate. Cumulative \% TBW loss for all species increased linearly with time indicating a constant rate of water loss for a given species (Figs. 1 and 2, Tables 3 and 4). Mean percent of TBW lost per four hours varied widely ranging from 1.592 in G. malayus to 8.995 in Species A (order wise Polydesmida 7.446, Spirobolida 6.003, Spirostreptida 1.895) (calculated from Table 3). The mean percent of TBW lost per four hours in Polydesmida differed significantly with that of other two orders (Spirobolida and Spirostreptida) $(\mathrm{t}=2.643, \mathrm{P}<0.05)$. So 
by reducing rate of loss of TBW, spirobolidans and spirostreptidans can tolerate desiccation more efficiently compared to polydesmidans. In other words, smaller millipedes are more susceptible to desiccation compared to larger one. As the percent of TBW lost represents depletion of water reserves, EDNEY (1977) considered the rate of percent TBW loss over time a more accurate reflection of interaction between water reserves and a desiccation environment than does percent wet weight lost over time.

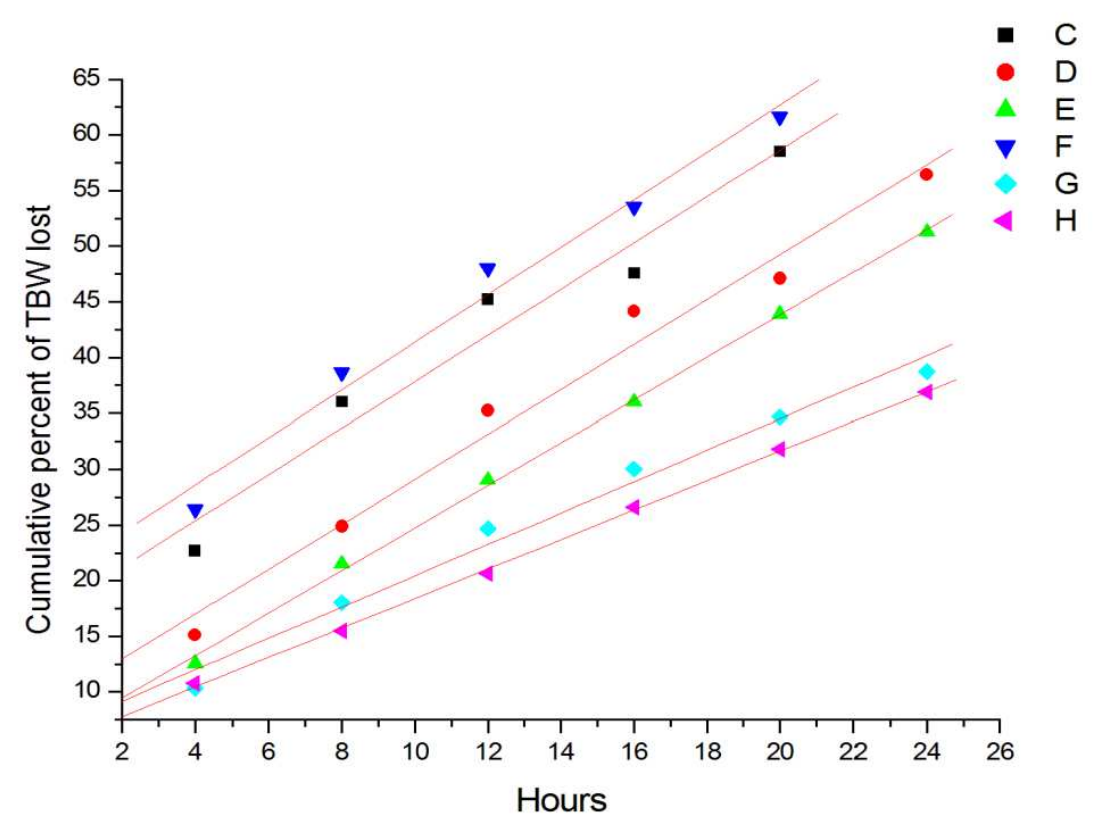

Fig. 1. Cumulative percent of TBW (mean) lost over time (hours) of six species of Polydesmida: $\mathrm{C}=$ Species $\mathrm{A} ; \mathrm{D}=P$. kelaarti $; \mathrm{E}=C$. severini $; \mathrm{F}=O$. coarctata $; \mathrm{G}=A$. saussurii $; \mathrm{H}=S$. phipsoni.

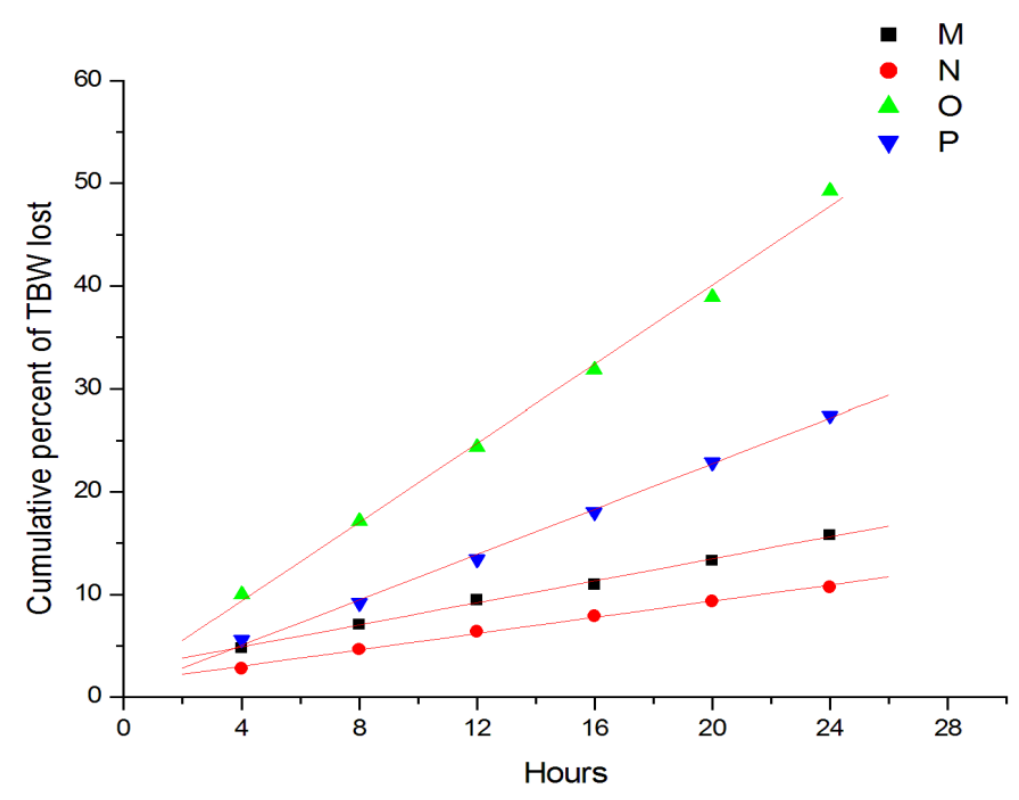

Fig. 2. Cumulative percent of TBW (mean) lost over time (hours) of two species of Spirostreptida: $\mathrm{M}=$ Species $\mathrm{B} ; \mathrm{N}=$ G. malayus and two species of Spirobolida; $\mathrm{O}=X$. carnifex $\mathrm{P}=T$. lumbricinus

In general, the pattern of larger millipedes being less susceptible to water loss than smaller ones (CRAWFORD, 1979) was consistent with the findings of this study (Table 5). Species A and $O$. coarctata are smaller in size and died within $20 \mathrm{~h}$, but the largest one G. malayus, 
survived more than $300 \mathrm{~h}$ (Table 2). Mortality (hour of death) was negatively correlated with species' surface volume ratio $(\mathrm{Q})$ (Mortality=140.75Q-62.59, r2=0.5679, $\mathrm{P}<0.01$ ).

Table 5. The relationship between millipede species body size $(\mathrm{n}=10)$ and percentage of TBW lost over time $(4-24 \mathrm{~h})(\mathrm{P}<0.01)$.

\begin{tabular}{ccc}
\hline Hour & Regression equation & $\mathbf{r}^{2}$ \\
\hline 4 & $\mathrm{Y}=20.92-0.21 \mathrm{X}$ & 0.5831 \\
8 & $\mathrm{Y}=32.70-0.32 \mathrm{X}$ & 0.5916 \\
12 & $\mathrm{Y}=42.43-0.40 \mathrm{X}$ & 0.6133 \\
16 & $\mathrm{Y}=49.12-0.44 \mathrm{X}$ & 0.6374 \\
20 & $\mathrm{Y}=57.61-0.51 \mathrm{X}$ & 0.6480 \\
24 & $\mathrm{Y}=55.99-0.42 \mathrm{X}$ & 0.5141 \\
\hline
\end{tabular}

$\mathrm{Y}=$ Cumulative percentage of TBW lost and $\mathrm{X}=$ Size classes (in $\mathrm{mm}$ ).

In comparison with spirostreptidans, analyzed spirobolidans and polydesmidans showed more susceptibility to water loss and died earlier. This can be explained by the fact that both these orders (Spirobolida and Polydesmida) do not possess a spiracular closing mechanism (STEWART and WoOdRING, 1973) whereas, Spirostreptida can control water loss much more efficiently during movement in the dry surface by regulating the bean shaped structure guarding the spiracle (DWARAKANATH and JOB, 1965).

\section{CONCLUSION}

This study showed that within analyzed species smaller forms are mostly restricted to hygric habitat, while larger ones tend to live in xeric habitat. Moreover, smaller species having higher $\mathrm{CP}$ value and lower water reserve are more prone to desiccation compared with larger species. Obviously characteristics of millipede (water conservation and desiccation tolerance) determine their distribution in soil environments with variable moisture content (hygric, mesic and xeric). Furthermore, results of this study showed that differences in body size influence a millipede's ability to retain and conserve water, mortality and choice of habitat as well. Moreover, rate of percent of TBW loss over time is higher in analyzed polydesmidans. Hence polydesmidans millipede are less desiccations tolerant and restricted to hygric environments, whereas, spirobolidanss and spirostreptidans millipede species can tolerate desiccation to a large extent and are confined to mesic or xeric habitats.

\section{Acknowledgement}

I am deeply indebted to the anonymous reviewer for his untired efforts to enrich my paper for wider audience. I am also grateful to Mr. Soumendranath Bhakat for technical help.

\section{References:}

[1] Appel, A.G., Reierson, D.A., Rust, M.K. (1983): Comparative water relations and temperature sensitivity of cockroaches. Comp. Bioch. Physiol. 74A: 357-361.

[2] APPEL, A.G. (1988): Water relations and deciccation tolerance of migrating garden millipedes (Diplopods; Paradoxosomatidae). Environ. Entomol. 17 (3): 463-466. 
[3] APPEL, A.G., SPONSLER, R.C. (1989): Water and temperature relations of the primitive Xylophagous cockroach Cryptocercus punctulatus Scudder (Dictyoptera: Cryptocercidae). Proc. Entomol. Soc. Wash. 91 (2): 153-157.

[4] APPEL, A.G., MiLler, M.K., MACK, T.P. (1991): Cutaneous water loss of several stages of the red imported fire ant, Solenopsis invicta (Buren). Comp. Biochem. Physiol. 98A (2): 281-283.

[5] BARLOW, C.A. (1957) A factorial analysis of distribution in three species of diplopods. Tijidschr. Ent. 100: 349-426.

[6] BHAKAT, S. (1987): Ecology of an Indian grassland millipede Streptogonopus phipsoni (Diplopoda: Polydesmoidea). J. Zool. Lond. 212: 419-428.

[7] Bligh, J., Cloudsley-Thompson, J.L., Macdonald, A.G. (1976): Environmental physiology of animals. Blackwell Scientific Publications, Oxford.

[8] Blower, J.G, GabbutT, P.D. (1964): Studies on the millipedes of a Devon oak wood. Proc. Zool. Soc. Lond. 143: 143-176.

[9] Blower, J.G., MiLler, P.F. (1977): The life-history of the julid millipede Cylindroiulus nitidus in a Derbyshire wood. J. Zool. Lond. 183: 339-351.

[10] BuRSELL, E. (1955): The transpiration of terrestrial isopoda. J. Exp. Biol. 32: 238-225.

[11] BUXTON, P.A. (1932): Terrestrial insects and the humidity of the environment. Biol. Rev. 7: 275-320.

[12] Cloudsley-Thompson, J.L. (1950): The water relations and cuticle of Paradesmus gracilis (Diplipoda, Strongylidae). Quart. J. Micr. Sci. 91: 453-464.

[13] Cloudsley-Thompson, J.L. (1960): Adaptive functions of circadian rhythms. Cold Spr. Harb. Symp. quant. Biol. 25: 345-355.

[14] Cloudsley-Thompson, J.L. (1961): Rhythmic activity in animal physiology and behavior. Academic Press, New York and London.

[15] Cloudsley-Thompson, J.L. (1975): Terrestrial Environments. Croom Helm, London.

[16] CRAWFORD, C.S. (1972): Water relations in a desert millipede Ornatus ornatus (Girard) (Spirostreptidae). Com. Bioch. Physiol. 42A: 521-535.

[17] CRAWford, C.S. (1979): Desert millipedes a rationale for their distribution. In: M. Camatini (Ed.) Myriapod Biology. London, Academic Press: 171-181.

[18] Crawford, C.S., Goldenberg S., Warburg. M.R. (1986): Seasonal water balance in Archispirostreptus syriacus (Diplopoda: Sprirostrieptidae) from mesic and xeric Mediterranean environments. J. Arid. Environ. 10: 127-136.

[19] DAngerfield, J.M., MiLNER, A.E. (1993): Ingestion and assimilation of leaf litter in some tropical millipedes. J. Zool. 229: 683-693.

[20] Dwarakanath, S.K., Job, S.V. (1965): Studies on transpiration in millipedes. Proc. Indian Acad. Sci. 62: 228.

[21] EDNEY, E.B. (1951): The evaporation of water from wood lice and the millipede Glomeris. J. Exp. Biol. 28: 91-115.

[22] EDNEY, E.B. (1977): Water balance in land arthropods. Springer, New York.

[23] Loveridge, J.P. (1980): Cuticular water relations techniques. In: Miller, T.A. (Ed.) Cuticle Techniques. Springer, New York: 301-366.

[24] MaChIN, J. (1981): Water compartmentalization in insects. J. Exp. Zool. 215: 327-333.

[25] MACK, T.P., APPEL, A.G. (1986): Water relations of immature and adult lesser constalk borers, Elasmopalpus lignosellus (Lepidoptera; Pyralidae). Ann. Entomol. Soc. Amer. 79: 579-582.

[26] Mack, T.P., ApPel, A.G., Backman, C. B., Trichilo, P.J. (1988): Water relations of several arthropod predators in the peanut agroecosystem. Environ. Entomol. 17 (5): 778 781.

[27] MeAd-Briggs, A.R. (1956): The effect of temperature upon the permeability to water of arthropod cuticles. J. Exp. Biol. 33: 737-749. 
[28] Sponsler, R.C., APPEL, A.G. (1990): Aspects of the water relations of the Formosan and subterranean termites (Isoptera: Rhinotermitidae). Environ. Entomol. 19 (1): 15-20.

[29] Stewart, T.C., Woodring, J.P. (1973): Anatomical and plysiological studies of water balance in the millipedes Pachydesmus crassicutis (Polydesmida) and Orthoporus texicolens (Spirobolidae). Comp. Bioch. Physiol. 44A: 734-750.

[30] TOYE, S.A. (1967): Observations on the biology of three species of Nigerian millipedes. $J$. Zool. 152: 67-78. 